\title{
Biostratigraphy of Late Maastrichtian larger foraminifers in Jamaica and the importance of Chubbina as a Late Maastrichtian index fossil
}

\author{
SIMON F. MITCHELL \\ Department of Geography and Geology, University of the West Indies, Mona, Kingston 7, Jamaica (e-mail: smitchell@cwjamaica.com).
}

\begin{abstract}
The succession of larger foraminifers from the White Rock River Bridge section of the Guinea Corn Formation (Late Maastrichtian) in Jamaica, West Indies, contains: Sulcoperculina dickersoni (Palmer), Ayalaina rutteni (Palmer), Orbitoides cf. megaloformis Papp \& Küpper, Vaughania cubensis Palmer and Chubbina cardenasensis (Barker \& Grimsdale). A. rutteni occurs in the lower beds and C. cardenasensis occurs in the upper beds. The orbitoid foraminifer Or. cf. megaloformis is restricted to the middle beds. The White Rock River Bridge Section can be correlated to the standard Guinea Corn successions using lithological/biostratigraphic markers and rudist marker beds, and linked ages derived from $\mathrm{Sr}$-isotope values. This indicates that $\mathrm{Or}$. cf. megaloformis occurs in the last $1.3 \mathrm{Ma}$ of the Cretaceous in the Caribbean and that its evolution was retrograde compared to coeval populations in Europe. The first appearance of Chubbina represents a valuable datum since the genus occurs in various different biofacies (both with and without orbitoid foraminifers) and allows correlation in the Caribbean, Central America and Florida. J. Micropalaeontol. 24(2): 123-130, October 2005.
\end{abstract}

KEYWORDS: Foraminifera, biostratigraphy, Guinea Corn Formation, Upper Cretaceous, Jamica

\section{INTRODUCTION}

The most important section of rudist-bearing, shallow-water, platform-type limestones in Jamaica is exposed in the Central Inlier (Coates, 1965; Mitchell \& Blissett, 2001; Mitchell, 2002). These limestones are known as the Guinea Corn Formation and contain rudist assemblages dominated by Titanosarcolites and Chiapasella. The most complete section is exposed in the Rio Minho between Grantham and Frankfield, and was described in detail by Mitchell (1999), who introduced a bed lettering system (beds labelled from A to $\mathrm{G}$ ) for the limestones based on variations in lithology. Two Chiapasella zones were erected by Mitchell \& Gunter (2002) and five strontium isotope ages, using well-preserved calcite from the outer shell layer of rudists, were given by Steuber et al. (2002).

Despite the large amount of data collected from these sections in the Rio Minho, an outstanding problem is the stratigraphic distribution of the larger foraminifers. Although Kathina, Sulcoperculina and Chubbina are common in certain beds (e.g. Robinson, 1968), larger foraminifers, such as Orbitoides, Pseudorbitoides, Omphalocyclus and Vaughania are not present, although they were reported to be abundant elsewhere in Jamaica (Jiang \& Robinson, 1987; Krijnen et al., 1993; Gunter et al., 2002), but not from measured sections. Broadly coeval larger foraminifers are also distributed widely elsewhere in the Caribbean (Cuba: Palmer, 1934; Rutten, 1935; Brönnimann, 1954a, b, 1955a, b, 1956; Seiglie \& Ayala-Castañares, 1963), Central America (Mexico: Ayala-Castañares, 1963; RosalesDomínguez et al., 1997; Caus et al., 2002), South America (Venezuela: Renz, 1955) and Florida (Cole \& Applin, 1970) and have been correlated with the European Orbitoides succession (Caus et al., 1996).

In this paper, a section exposed in the White Rock River near the village of Tweedside is described (Fig. 1). This section contains lithological and faunal marker beds that allow a correlation with the standard Guinea Corn succession in the Rio Minho, and abundant larger foraminiferal assemblages. This allows for the first time an independent dating of the supposed Late Campanian-Early Maastrichtian Orbitoides succession in the Caribbean and demonstrates that the Orbitoides evolutionary pattern in the Caribbean is retrograde when compared to Europe. Furthermore, Chubbina is restricted to the Late Maastrichtian and should prove a valuable index fossil in sections around the Caribbean Plate.

\section{METHODOLOGY}

The section in White Rock River was logged and samples were collected for foraminifers at regular intervals throughout the section. Bulk samples of siltstones/mudstones were collected from the softer layers (WR and TM prefixes). These were dried in an oven and sieved through a $125 \mu \mathrm{m}$ sieve. Foraminifers were picked using a binocular microscope. In the intervals lacking suitable soft lithologies, limestone samples were collected (Samples 1 to 9). Ten thin sections were prepared from each sample and the foraminifers identified under a binocular microscope.

For the specimens of Orbitoides in the soft layers, equatorial thin sections were prepared. Eight thin sections were prepared, but four of these were strongly recrystallized and did not show the embryonic apparatus. Additionally, equatorial thin sections from the studies of Jiang \& Robinson (1987) and Gunter et al. (2002) were also examined. Measurements of the embryonic apparatus of Orbitoides follow Caus et al. (1996 and references therein). The maximum and minimum diameters of the outside ( $L_{\mathrm{o}}$ and $l_{\mathrm{o}}$, respectively), and inside ( $L_{\mathrm{i}}$ and $l_{\mathrm{i}}$, respectively) of the embryonic apparatus, together with the number of epi-auxillary chambers $(E)$ were measured. These are compared graphically with plots of $L_{\mathrm{o}}+l_{\mathrm{o}}$ versus $E$ and $L_{\mathrm{o}}+l_{\mathrm{o}}$ versus $L_{\mathrm{i}}+l_{\mathrm{i}}$ for populations of Orbitoides from Europe (Caus et al., 1996).

All samples are housed in the Geology Museum at the University of the West Indies (UWIGM numbers). Representative foraminifers in thin section are shown in Plate 1. 


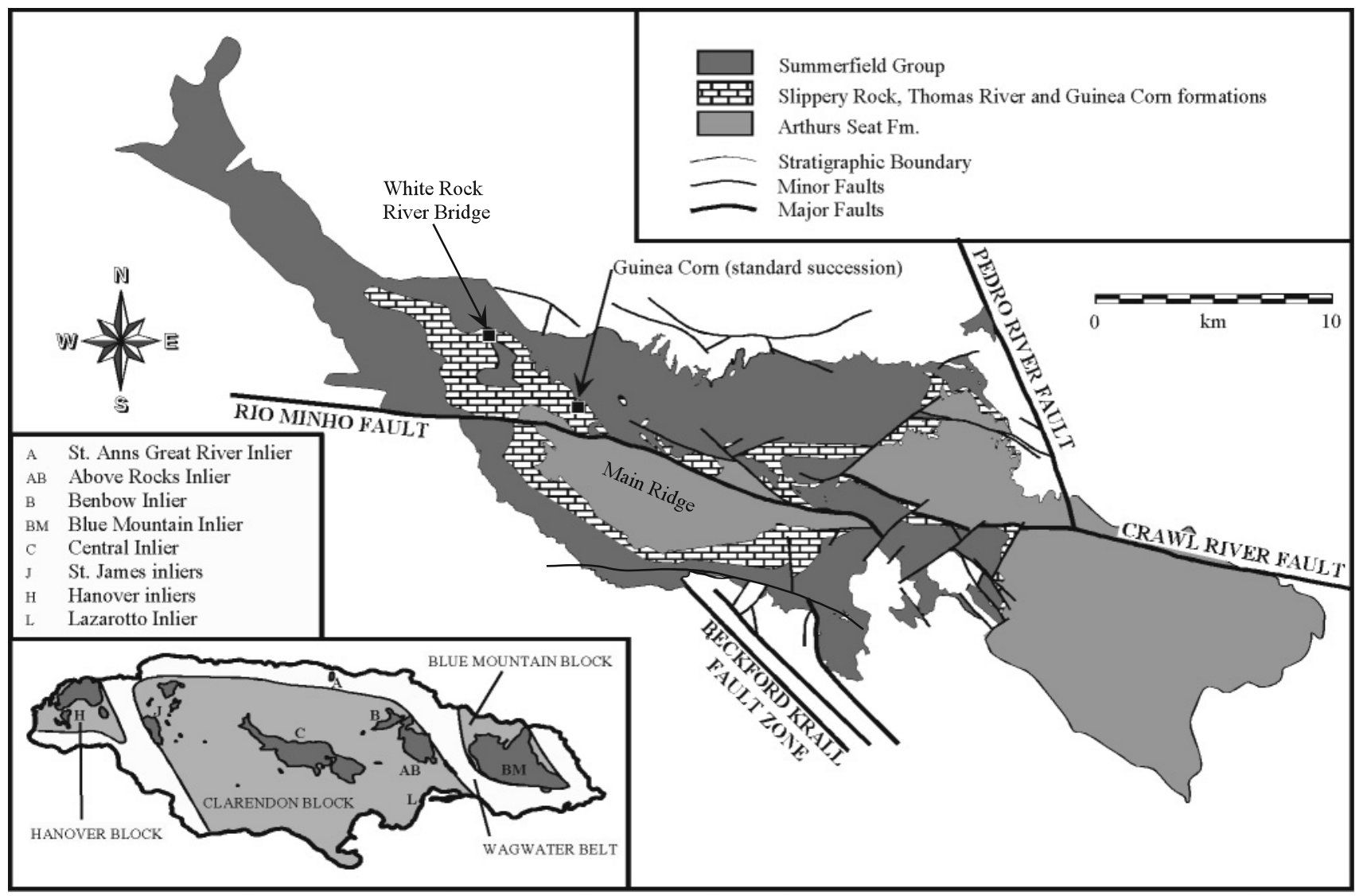

Fig. 1. Location of the White Rock River Bridge and standard (Guinea Corn) sections in the Central Inlier of Jamaica. Inset, distribution of Cretaceous inliers in Jamaica.

\section{WHITE ROCK RIVER BRIDGE SECTION}

The White Rock River Bridge section exposes a near-continuous succession of limestones with subsidiary mudstones. A total of $86 \mathrm{~m}$ was logged (Fig. 2). The lower part of the section is exposed in the White Rock River in the $100 \mathrm{~m}$ upstream of the bridge. The base of the Guinea Corn Formation is not seen. The upper part of the section is exposed along the road on the southern side of the bridge, although the junction with the overlying Green River Formation, Summerfield Group, is concealed.

The lower $11 \mathrm{~m}$ of section consists of bioclastic limestones with scattered rudists including Titanosarcolites sp., Bournonia thiadensi Vermunt and Biradiolites jamaicensis Trechmann. Two important marker horizons are a rudist rudstone (Mac 1) containing abundant Macgillavryia nicholasi (Whitfield) with an impure, calcarenitic matrix, and a white micritic limestone (Mac 2) with scattered $M$. nicholasi. Sample WR 5 yielded only Kathina jamaicensis (Cushman \& Jarvis). The two Macgillavryia beds correlate with similar beds in the standard Guinea Corn succession. Mac 1 correlates with the Praebarrettia Bed at the top of the D Beds of Mitchell (1999). The name Praebarrettia Bed is not retained here since Praebarrettia itself is not common even in the standard succession, whereas Macgillavryia is abundant. Mac 2 correlates with the Macgillavryia Bed of Mitchell (1999) in Bed F1 of the standard succession; in both sections Mac 2 is represented by a prominent white limestone.
Above Mac 2 there is a marked facies change from limestones to marls with nodules. The succeeding $7 \mathrm{~m}$ consists of nodular limestones and mudstones. At the top of this interval is a prominent bedset composed of thin platy limestones with mudstones between. Rudists are rare in these beds and limited to scattered examples of Antillocaprina williamsi Chubb. Other prominent macrofossils include Neithea sp., Hamulus sp. and Hemiaster sp. The foraminiferal assemblage (samples WR 14 \& 18) includes Kathina jamaicensis and Sulcoperculina dickersoni (Palmer). The succession can be correlated bed-for-bed, because of the similarities in lithologies, with F1 of the standard Rio Minho section (Fig. 2).

The following $5 \mathrm{~m}$ are composed of mudstones with a single limestone, whereas the overlying $5 \mathrm{~m}$ are represented by micritic limestones. The lower part of the latter limestone (WR 30) yields abundant specimens of Orbitoides. The succeeding $15 \mathrm{~m}$, or so, of section consists of mudstones with several thin limestones. Rudists are absent, whereas branching corals and echinoids (Hemiaster sp. and tests and spines of Phyllocanthas leoni Papp \& Küpper) are abundant. The foraminifers (samples WR34, 40, 44, 61 \& 71) include S. dickersoni, K. jamaicensis and Ayalaina rutteni (Palmer).

There is then a major facies change from silty mudstones to thickly bedded limestones that continue up to the top of the formation (Fig. 2). Rudists are generally rare, although a few Antillocaprina and Titanosarcolites sp. are present. Three 

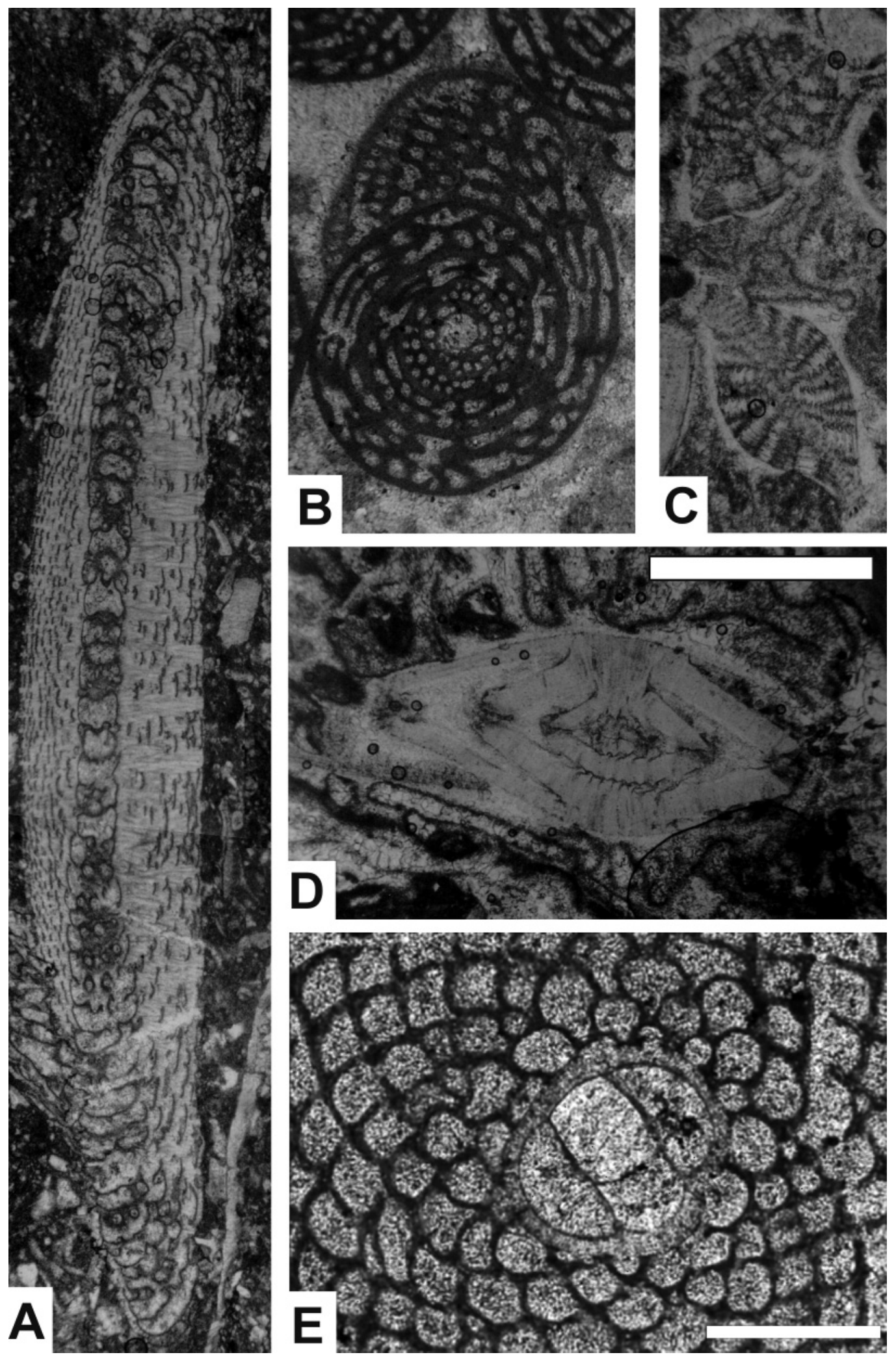

Explanation of Plate 1.

Larger foraminifers from the Guinea Corn Formation at White Rock River Bridge. (A) Orbitoides cf. megaloformis Papp \& Küpper, sample WW1; (B) Chubbina cardenasensis (Baeker \& Grimsdale), G Beds, standard Guinea Corn section; (C) Vaughania cubensis Palmer, sample WW5; (D) Sulcoperculina dickersoni (Palmer), sample WW8; (E), Or. cf. megaloformis, embryonic apparatus, Sample WR29. Scale bar for (A)-(D) (shown on (D)) $1 \mathrm{~mm}$; scale bar for (E) $100 \mu \mathrm{m}$. All specimens preserved in UWIGM. 


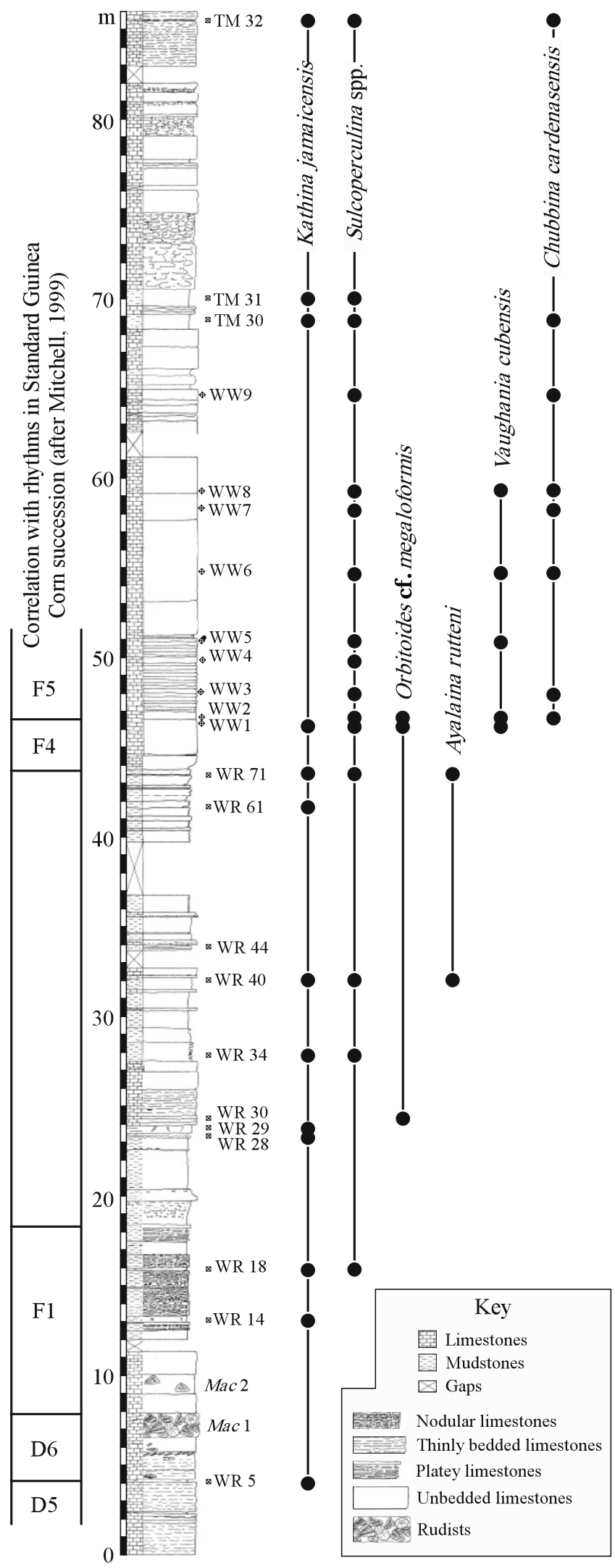

Fig. 2. Graphic log of the White Rock River Bridge section showing the distribution of foraminifers. Marker beds correlated from the standard Guinea Corn succession are also shown (after Mitchell, 1999). important foraminifers are present. Samples WW1 and WW2 (Fig. 2) contain abundant Orbitoides and Vaughania cubensis Palmer. Sample WW2 also sees the first appearance of Chubbina cardenasensis (Barker \& Grimsdale) (=Chubbina jamaicensis Robinson, 1968, =Chubbina macgillavryi Robinson, 1968). This species remains abundant throughout the remainder of the Guinea Corn Formation. V. cubensis occurs consistently up to sample WW8. The appearance of Chubbina in the standard Rio Minho section is between rhythms F4 and F5 of Mitchell (1999).

\section{FORAMINIFER BIOSTRATIGRAPHY}

Orbitoides has been used as an important zone fossil in the Upper Cretaceous of Europe (see summary in Caus et al., 1996), where successive species show an increase in size of the embryonic apparatus and an increase in the number of epi-auxillary chambers. The critical measurements of Jamaican specimens are shown in Table 1. Plots of $L_{\mathrm{o}}+l_{\mathrm{o}}$ versus $E$ show that the Jamaican material falls between the ranges of Or. megaloformis and Or. gruenbachensis Papp (Fig. 3), although the range of both variables in the Jamaican population is larger than in either of these species. Plots of $L_{\mathrm{o}}+l_{\mathrm{o}}$ versus $L_{\mathrm{i}}+l_{\mathrm{i}}$ show that the Jamaican population has notably small values of $L_{\mathrm{i}}+l_{\mathrm{i}}$ (comparable with Orbitoides media (d'Archiac)) than the European populations for the same range of $L_{\mathrm{o}}+l_{\mathrm{o}}$ values (Fig. 3). The Orbitoides population from Jamaica is referred to here as Or. cf. megaloformis.

The age of the Guinea Corn Formation was determined by Steuber et al. (2002) from strontium isotope values in wellpreserved calcite from the outer shell layer of the rudists Chiapasella and Plagioptychus. Five samples were analysed from the Central Inlier (Table 2). The four samples from the standard section of the Guinea Corn Formation are all below the equivalent of the Orbitoides level in the White Rock River Bridge section. The Logie Green sample is from immediately to the west of the Orbitoides exposure of Jiang \& Robinson (1987) and contains the rudists Chiapasella radiolitiformis (Trechmann) and Bournonia barretti Trechmann, indicating a level in the Middle C Beds. Therefore, the ages derived from strontium isotope values indicate that the Orbitoides level in the Central Inlier is in the latest Late Maastrichtian. Figure 4 compares the distribution of Orbitoides species in Europe (Caus et al., 1996) with the Orbitoides level from Jamaica. It is clear from this, that the Jamaican Orbitoides are phylogenetically retrograde when compared with coeval European Orbitoides. This has important implications for the use of Orbitoides as a biostratigraphic indicator outside of Europe.

Ayalaina rutteni has not previously been recorded from the Central Inlier. The level at which it occurs in the White Rock River Bridge section is probably broadly equivalent to its highest occurrence in the Popkin Formation of the Maldon Inlier (Gunter \& Mitchell, 2005).

Chubbina enters at the top of the distribution of Or. cf. megaloformis in the White Rock River Bridge Section (Fig. 2). Its first appearance is an important datum in Jamaica (e.g. Mitchell, 1999) and around the Caribbean region (Fig. 5). This datum can be used in the field, since Chubbina can be recognized with a hand lens. 
Late Maastrichtian larger foraminifers of Jamaica

\begin{tabular}{|c|c|c|c|c|c|}
\hline Specimens & $L_{\mathrm{o}}(\mu \mathrm{m})$ & $l_{\mathrm{o}}(\mu \mathrm{m})$ & $L_{\mathrm{i}}(\mu \mathrm{m})$ & $l_{\mathrm{i}}(\mu \mathrm{m})$ & $E$ \\
\hline \multirow{2}{*}{ Specimens from White Rock River Bridge section, Guinea Corn Formation } & 443 & 403 & 383 & 307 & 9 \\
\hline & 413 & 371 & 336 & 283 & 9 \\
\hline \multirow[t]{3}{*}{ Specimens illustrated by Krijnen et al. (1993), Guinea Corn Formation } & 375 & 345 & 310 & 220 & 6 \\
\hline & 415 & 365 & 365 & 310 & 8 \\
\hline & 500 & 395 & 415 & 315 & 9 \\
\hline Specimens from Jiang \& Robinson (1987), Guinea Corn Formation & 355 & 323 & 297 & 246 & 8 \\
\hline \multirow[t]{3}{*}{ Specimens from Gunter et al. (2002), Maldon Formation. } & 359 & 291 & 262 & 227 & 8 \\
\hline & 460 & 364 & 374 & 249 & 11 \\
\hline & 454 & 380 & 345 & 268 & 9 \\
\hline
\end{tabular}

Table 1. Measurements of critical values for Jamaican specimens of Orbitoides.

\section{DISCUSSION}

Orbitoides only occurs in the middle part of the White Rock River Bridge section. Krijnen et al. (1993, p. 39) suggested that further west in the Central Inlier, the orbitoid foraminifers had a 'more or less uniform vertical distribution'. Detailed geological mapping in this area indicates instead that all the traverses that Krijnen et al. (1993) undertook in the western part of the inlier are within the same Orbitoides-yielding horizon as in the White Rock River section.

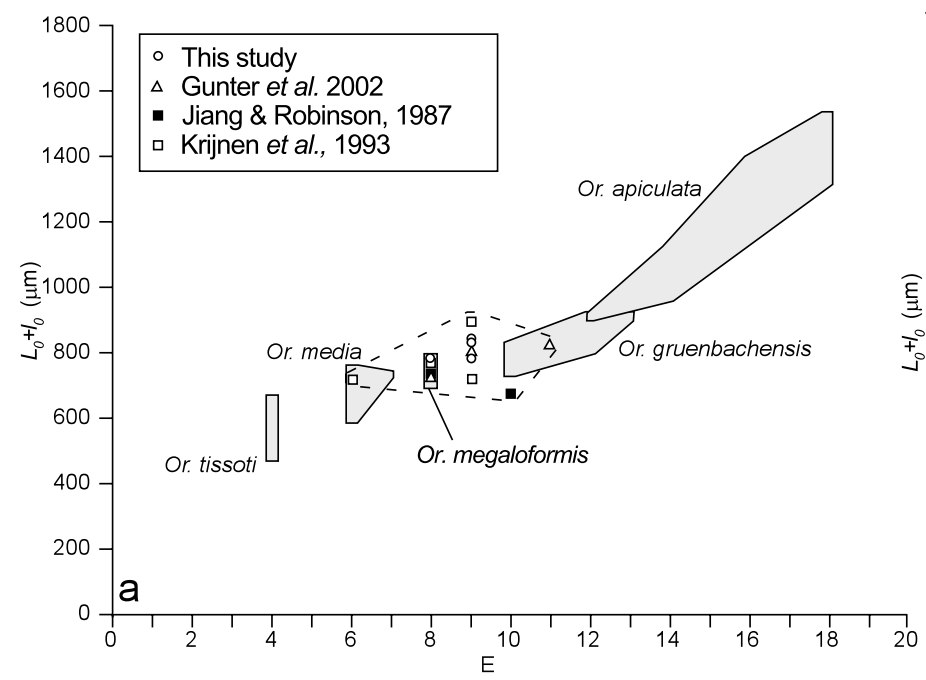

Fig. 3. Graphic plots for Orbitoides: (a) plot of $L_{\mathrm{o}}+l_{\mathrm{o}}$ versus $E$ for populations of Orbitoides from Europe (Caus et al., 1996). Jamaican specimens fall between the plots of Or. megaloformis and Or. gruenbachensis; (b) plot of $L_{\mathrm{o}}+l_{\mathrm{o}}$ versus $L_{\mathrm{i}}+l_{\mathrm{i}}$ for populations of Orbitoides from Europe (Caus et al., 1996). Jamaican specimens have smaller values of $L_{\mathrm{i}}+l_{\mathrm{i}}$ (for the same $L_{\mathrm{o}}+l_{\mathrm{o}}$ ) compared with the European populations. Data from Gunter et al. (2002), Jiang \& Robinson (1987) and Krijnen et al. (1993).

\begin{tabular}{lcrr}
\hline Unit & $\begin{array}{c}\text { Mean }{ }^{87} \mathrm{Sr} /{ }^{86} \mathrm{Sr} \text { values } \\
\left( \pm 2 \mathrm{S.E.} \times 10^{-6}\right)\end{array}$ & $\begin{array}{c}\text { Age } \\
(\mathrm{Ma})\end{array}$ \\
\hline Lower C Beds & $0.770806( \pm 8)$ & $>66.21$ & 66.68 \\
Middle C Beds (D25) & $0.707813( \pm 7)$ & $>65.95$ & 66.39 \\
Bed D1 & $0.707809( \pm 7)$ & $>66.13$ & 66.55 \\
Bed F1 & $0.707827( \pm 8)$ & $>65.0$ & 65.78 \\
Logie Green & $0.707812( \pm 8)$ & $>65.95$ & 667.46 \\
\hline
\end{tabular}

Table 2. Ages derived from strontium isotope ratios of well-preserved skeletal calcite in rudist bivalves from the Central Inlier (from Steuber et al., 2002).
In the Maldon Inlier of Jamaica, the Maldon Limestone has yielded Omphalocyclus maldonensis Gunter et al., Or. cf. megaloformis and Asterorbis cf. havanensis Palmer (Gunter et al., 2002; Gunter \& Mitchell, 2005). The Maldon Limestone also yields the rudist Chiapasella trechmanni Mitchell \& Gunter, which suggests a correlation with a level in the D Beds of the standard Guinea Corn succession (Fig. 5; Mitchell \& Gunter, 2002).

In Cuba, rich larger foraminiferal assemblages have been reported by Seiglie \& Ayala-Castañares (1963). Three assem-

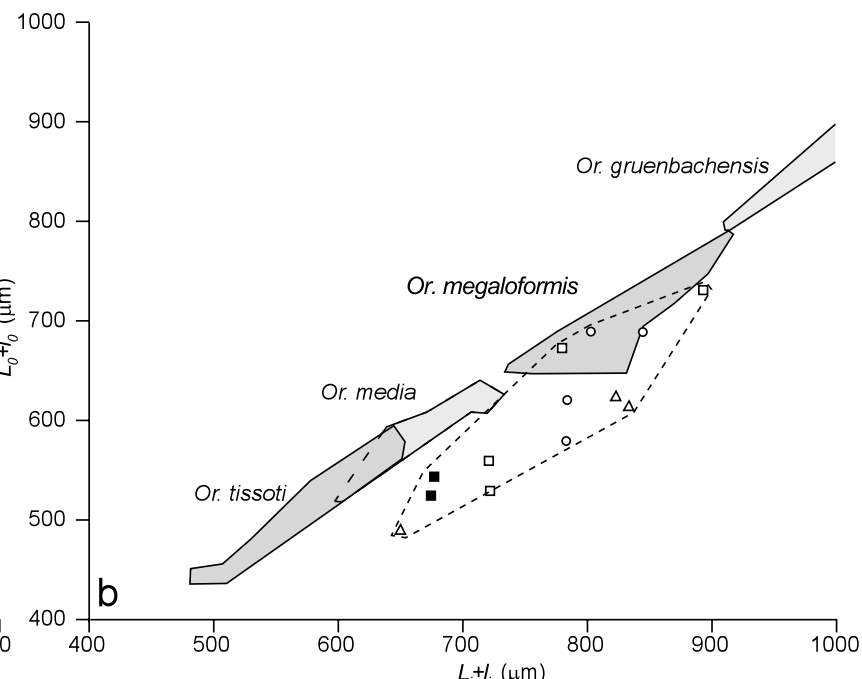




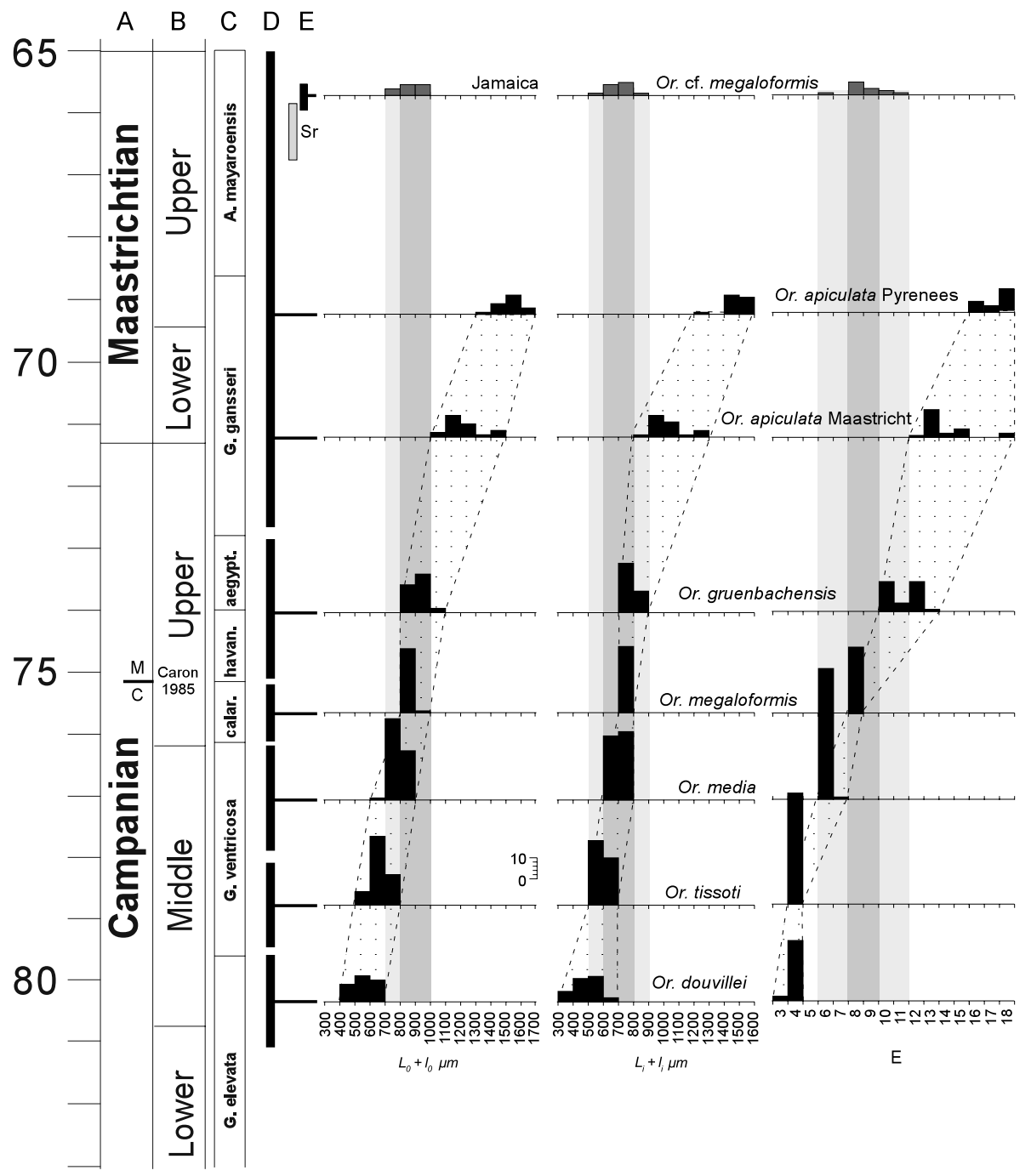

Fig. 4. Evolution of Orbitoides (black histograms) in Europe based on data in Caus et al. (1996). Jamaican population (grey histograms) of Or. cf. megaloformis shows more primitive characters in each case. A, stages; B, substages; C, planktonic foraminiferal zones from Caron (1985); D, stratigraphic range of Orbitoides species in Europe (from Caus et al. (1996); E, range of Or. cf. megaloformis in Jamaica together with age range derived from Sr-values (Steuber et al., 2002). Base of Maastrichtian adjusted based on Gradstein et al. (1995).

blage zones were recognized, an Orbitoides tissoti-Sulcorbitoides pardoi Zone, an Orbitoides media-Pseudorbitoides rutteni Zone, and an Orbitoides apiculata-Omphalocyclus Zone. Chubbina cardenasensis was listed commonly from the Orbitoides apiculata-Omphalocyclus Zone and as a rare element in the Orbitoides media-Pseudorbitoides rutteni Zone.

In Sierra de Chiapas, southeastern Mexico, Late CampanianMaastrichtian foraminiferal assemblages have been discussed by Ayala-Castañares (1963) and Rosales-Domínguez et al. (1997). Rosales-Domínguez et al. (1997) recognized three assemblages: wackestones with planktonic foraminifera considered to be of Late Campanian-Early Maastrichtian age; packstones with larger benthic foraminifera of Campanian-Maastrichtian age; and a packstone with Chubbina considered to be of Maastrichtian age. Ayala-Castañares (1963) recognized two assemblages of larger foraminifera: an Upper Campanian assemblage containing Orbitoides tissoti Schlumberger, Lepidorbitoides minima H. Douvillé, Sulcoperculina sp. and Pseudorbitoides sp.; and an
Upper Maastrichtian (probably partly Lower Maastrichtian) assemblage with Orbitoides apiculata browni (Ellis), Smoutina bermudezi (Cole), Vaughania cubensis and Sulcoperculina sp. Caus et al. (2002) and Aguilar et al. (2002) considered that the type section from which L. minima was described, and which contained a larger foraminiferal assemblage consisting of $L$. minima, Sulcoperculina dickersoni, S. globosa de Cizancourt, Smoutina? sp., $V$. cf. cubensis and fragments of Ayalaina and Orbitoides, was of upper Middle to lower Upper Campanian age.

In southern Florida, Chubbina has been reported from the upper Lawson Limestone, just below the top of the Cretaceous (Cole \& Applin, 1970).

Gunter et al. (2002) pointed out that two orbitoid foraminiferal assemblages appear to be represented in the Maastrichtian of the Caribbean-Central American Tethys. An assemblage with Orbitoides megaloformis, Omphalocyclus maldonensis, Vaughania cubensis with Asterorbis havanensis and Pseudorbitoides rutteni 


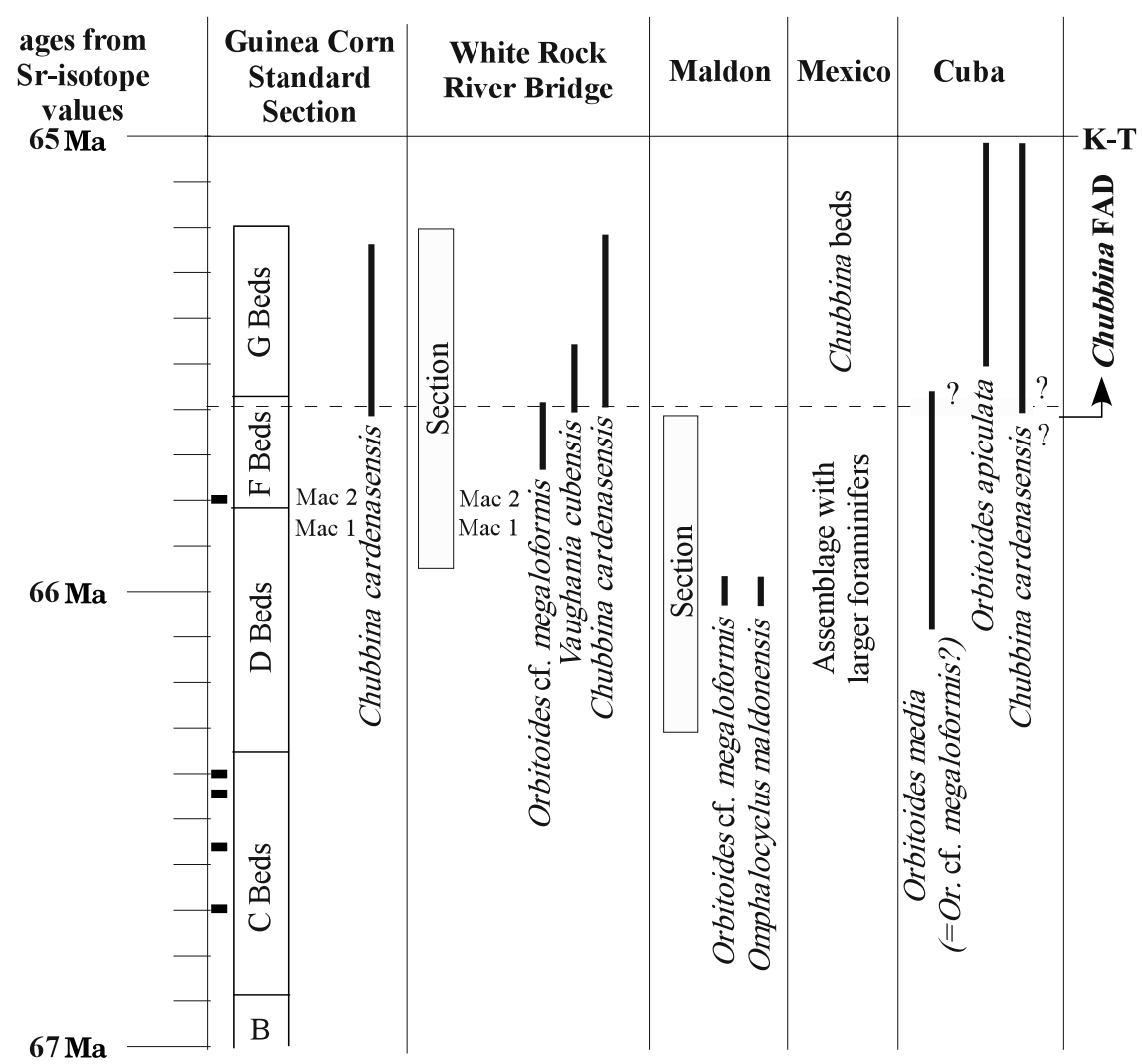

Fig. 5. Correlation of larger foraminifer successions in the Caribbean and Mexico using first appearance datum (FAD) of Chubbina. Chronostratigraphy based on ages derived from Sr-isotopic values (Steuber et al., 2002), shown on right as black bars.

in Jamaica (Krijnen et al., 1993; Gunter et al., 2002). Elements of this assemblage are also seen in Cuba (Seiglie \& AyalaCastañares, 1963) and probably Venezuela (Renz, 1955; Gunter et al., 2002). In the White Rock River Bridge section, Chubbina enters in the upper part of this assemblage zone.

A second assemblage with Orbitoides apiculata, Omphalocyclus macroporus (Lamarck), Asterorbis cubensis Palmer, Vaughania cubensis and Chubbina cardenasensis is present in Cuba (Seiglie \& Ayala-Castañares, 1963), while some of the elements are represented in Mexico (Orbitoides apiculata browni and Vaughania cubensis: Ayala-Castañares, 1963) and ?Jamaica (beds with Chubbina cardenasensis above the Or. cf. megaloformis level).

The Or. cf. megaloformis assemblage can be dated precisely in Jamaica using the Sr-isotope stratigraphy given by Steuber et al. (2002). The Or. cf. megaloformis level in the Maldon Limestone (Gunter et al., 2002) correlates with the D Beds, the base of which gave a Sr-isotopic age of $66.3(+0.14 /-0.15)$. The Or. cf. megaloformis beds in the White Rock River Bridge Section correlate with the middle and upper F Beds, F1 having given a Sr-isotopic age in the standard Rio Minho section of 65.81 $(+0.2 /-0.29)$. Thus, in Jamaica Or. cf. megaloformis ranges from 66.3 to $<65.8$ million years. This suggests that the succeeding Or. apiculata assemblage represents less than 800000 years at the end of the Maastrichtian (Fig. 5).

Chubbina is a much more widely distributed genus than Orbitoides in the Caribbean and occurs in both low diversity, restricted platform settings and in more open-water assemblages that contain diverse larger foraminifers. Chubbina appears in the upper part of the range of Or. cf. megaloformis and remains a prominent faunal member throughout the remainder of the Maastrichtian (Fig. 5). The first appearance of this genus is, therefore, a potentially important regional bioevent in the Late Maastrichtian of the Greater Caribbean Region (the Antilles, Florida, Central and northern South America).

\section{ACKNOWLEDGEMENTS}

The author is very grateful to Ian Brown for help with logging the section, and Sherene James and Ennika James for helping collect samples. Shakira Khan and the University of the West Indies Electron Microscope Unit helped with the photography of the foraminifers. Gavin Gunter allowed use of the thin sections of Orbitoides that he had prepared. Thank also to the reviewers (Dr E. Caus and one anonymous) and journal editor (John Gregory) for their useful reviews.

\section{Manuscript received 8 September 2003 Manuscript accepted 10 August 2004}

\section{REFERENCES}

Aguilar, M., Caus, E. \& Höttinger, L. 2002. Lepidorbitoides minima Douvillé from Mexico, a foraminiferal index fossil for the Campanian. Journal Foraminiferal Research, 32: 126-134.

Ayala-Castañares, A. 1963. Foraminiferos grandes del Cretacico Superior de la region central del Estado de Chiapas, Mexico. Parte 1. El genero Orbitoides D'Orbigny, 1847. Paleontologica Mexicana, 13: $57-73$ 
Brönnimann, P. 1954a. Upper Cretaceous orbitoidal Foraminifera from Cuba - Part 1. Sulcorbitoides n. gen.. Contributions to the Cushman Foundation for Foraminifera Research, 5: 55-62.

Brönnimann, P. 1954b. Upper Cretaceous orbitoidal Foraminifera from Cuba - Part 2. Vaughanina Palmer, 1934. Contributions to the Cushman Foundation for Foraminifera Research, 5: 91-105.

Brönnimann, P. 1955a. Upper Cretaceous orbitoidal Foraminifera from Cuba - Part 3. Pseudorbitoides H. Douvillé, 1922. Contributions to the Cushman Foundation for Foraminifera Research, 6: 57-76.

Brönnimann, P. 1955b. Upper Cretaceous orbitoidal Foraminifera from Cuba - Part 4. Rhabdorbitoides, n. gen. Contributions to the Cushman Foundation for Foraminifera Research, 6: 97-104.

Brönnimann, P. 1956. Upper Cretaceous orbitoidal Foraminifera from Cuba - Part 5. Historbitoides, n. gen. Contributions to the Cushman Foundation for Foraminifera Research, 7: 60-66.

Caron, M. 1985. Cretaceous planktic foraminifera. In: Bolli, H., Saunders, V. \& Perch-Nielsen, K. (Eds), Plankton Stratigraphy. Cambridge University Press, Cambridge, 17-86.

Caus, E., Bernaus, J.M. \& Gomez-Garrido, A. 1996. Biostratigraphic utility of species of the genus Orbitoides. Journal of Foraminiferal Research, 26: 124-136.

Caus, E., Tambareau, Y., Colin, J.-P., Aguilar, M., Bernaus, J.-M., Gomez-Garrido, A. \& Brusset, S. 2002. Upper Cretaceous microfauna of the Cárdenas Formation, San Luis Potosí, NE Mexico. Biostratigraphical, palaeoecological, and palaeogeographical significance. Revista Mexicana de Ciencias Geológicas, 19: 137-144.

Coates, A.G. 1965. A new section in the Maestrichtian Guinea Corn Formation near Crawle River, Clarendon. Journal of the Geological Society of Jamaica (Geonotes), 7: 28-33.

Cole, W.S. \& Applin, E.R. 1970. Analysis of some American Upper Cretaceous larger Foraminifera. Bulletins of American Paleontology, 58: $41-80$.

Gradstein, F.M., Agterberg, F.P., Ogg, J.G., Hardenbol, J., van Veen, P., Thierry, J. \& Huang, Z. 1995. A Triassic, Jurassic and Cretaceous timescale. In: Berggren, W.A., Kent, D.V., Aubry, M.-P. \& Hardenbol, J. (Eds), Geochronology, time scales and global stratigraphic correlation. SEPM special publication, 54: 95-126.

Gunter, G.C. \& Mitchell, S.F. 2005. The lithostratigraphy of the Maldon Inlier, northwestern Jamaica. Caribbean Journal of Earth Science, 38: 1-10.

Gunter, G.C., Robinson, E. \& Mitchell, S.F. 2002. A new species of Omphalocyclus (Foraminiferida) from the Upper Cretaceous of Jamaica and its stratigraphical significance. Journal of Micropalaeontology, 21: 149-153.
Jiang, M.-J. \& Robinson, E. 1987. Calcareous nannofossils and larger foraminifera in Jamaican rocks of Cretaceous to Early Eocene age. In: Ahmad, R. (Ed.), Proceedings of a workshop on the status of Jamaican geology. Special issue. Geological Society of Jamaica, 24-51.

Krijnen, J.P., MacGillavry, H.J. \& van Dommelen, H. 1993. Review of Upper Cretaceous orbitoid larger foraminifera from Jamaica, West Indies, and their connection with rudist assemblages. In: Wright, R.M. \& Robinson, E. (Eds), Biostratigraphy of Jamaica. Geological Society of America, Memoir, 182: 29-63.

Mitchell, S.F. 1999. Stratigraphy of the Guinea Corn Formation (Upper Cretaceous) at its type locality between Guinea Corn and Grantham (northern Clarendon, Jamaica). Journal of the Geological Society of Jamaica, 33: 1-12.

Mitchell, S.F. 2002. Palaeoecology of corals and rudists in mixed volcaniclastic-carbonate small-scale rhythms (Upper Cretaceous, Jamaica). Palaeogeography, Palaeoclimatology, Palaeoecology, 186: 237-259.

Mitchell, S.F. \& Blissett, D. 2001. Lithostratigraphy of the Late Cretaceous to ?Paleocene succession in the western part of the Central Inlier of Jamaica. Caribbean Journal of Earth Science, 35: 19-31.

Mitchell, S.F. \& Gunter, G.C. 2002. Biostratigraphy and taxonomy of the rudist Chiapasella in the Titanosarcolites Limestones (Maastrichtian) of Jamaica. Cretaceous Research, 23: 473-487.

Palmer, D.K. 1934. Some larger fossil Foraminifera from Cuba. Memoir Society Cubana Natural History, 8: 235-264.

Renz, H.H. 1955. Some Upper Cretaceous and lower Tertiary foraminifera from Arugua and Guarico Venezuela. Micropaleontology, 1: $52-71$.

Robinson, E. 1968. Chubbina, a new Cretaceous alveolinid genus from Jamaica and Mexico. Palaeontology, 2: 56-534.

Rosales-Domínguez, M. del C., Bermúdez-Santana, J.C. \& Aguilar-Piña, M. 1997. Mid and Upper Cretaceous foraminiferal assemblages from the Sierra der Chiapas, southeastern Mexico. Cretaceous Research, 18: 697-712.

Rutten, M.G. 1935. Larger foraminifera of northern Santa Clara Province, Cuba. Journal of Paleontology, 9: 527-545.

Seiglie, G.A. \& Ayala-Castañares, A. 1963. Sistematica y bioestratigrafia de los Foramiferos grandes del Cretacico superior (Campaniano y Maestrichtiano) de Cuba. Paleontologica Mexicana, 13: 3-40.

Steuber, T., Mitchell, S.F., Buhl, D., Gunter, G. \& Kasper, H.U. 2002. Catastrophic extinction of Caribbean rudist bivalves at the Cretaceous-Tertiary boundary. Geology, 30: 999-1002. 